\title{
Implementasi Metode Principal Component Analysis untuk Sistem Pengenalan Wajah
}

\author{
Fajar Sarasati ${ }^{1}$ Widiastuti $^{2}$, Elly Firasari ${ }^{3}$, F. Lia Dwi Cahyanti ${ }^{4}$ \\ 1,2,3,4 Universitas Nusa Mandiri \\ e-mail: ${ }^{1}$ fajar.fss@ nusamandiri.ac.id, ${ }^{2}$ widiastuti.wtu@nusamandiri.ac.id, ${ }^{3}$ elly.efa@ nusamandiri.ac.id \\ ,${ }^{4}$ flia.fdc@nusamandiri.ac.id

\begin{tabular}{ccc}
\hline Diterima & Direvisi & Disetujui \\
$29-11-2021$ & $02-12-2021$ & $03-12-2021$ \\
\hline
\end{tabular}

\begin{abstract}
Abstrak - Teknologi dimasa pandemic saat ini sangat dibutuhkan dalam berbagai bidang khususnya proses belajar mengajar yang dilaksanakan oleh hampir seluruh jenjang pendidikan, khususnya jenjang pendidikan tinggi. Namun pada kenyataannya mahasiswa justru tidak menggunakan media tersebut secara optimal bahkan saat ini jasa joki online dikalangan mahasiswa sudah berkembang menjadi bisnis global. Untuk mengatasi permasalahan tersebut diatas peneliti memanfaatkan teknologi Biometrics Authentication and Recognition. Dalam penelitian ini permasalahan yang diangkat yaitu bagaimana melakukan pengenalan wajah mahasiswa dalam sistem absensi di elearning yang digunakan untuk mendeteksi wajah mahasiswa untuk dapat mengakses sistem elearning tersebut. Pada penelitian yang dilakukan penulis saat ini dilakukan dengan menggunakan metode Principal Component Analysis menggunakan pengukuran jarak Euclidean untuk mencari kemiripan ciri suatu citra serta menghasilkan nilai maksimum dan minimum dari 50 citra yang diuji, sehingga akan diperoleh output wajah yang dikenali dan tidak dikenali, maka menghasilkan min distance terkecil sebesar $0.832 \%$ dari citra wajah Baijingting dan min distance terbesar dari citra wajah Aidai dengan jarak sebesar $0.973 \%$.
\end{abstract}

Kata Kunci: Implementasi, Principal Component Analysis, Pengenalan, Wajah

\section{PENDAHULUAN}

Teknologi dimasa pandemic saat ini sangat dibutuhkan dalam berbagai bidang khususnya proses belajar mengajar yang dilaksanakan oleh hampir seluruh jenjang pendidikan, khususnya jenjang pendidikan tinggi yang memanfaatkan konsep belajar mengajar dengan memanfaatkan teknologi informasi yakni media elearning yang dianggap efektif dalam melaksanakan proses belajar mengajar. Elearning diharapkan dapat memberikan fleksibilitas dalam memilih waktu dan tempat belajar, juga memberi kesempatan belajar secara mandiri bagi mahasiswa. Namun pada kenyataannya mahasiswa justru tidak menggunakan media tersebut secara optimal bahkan terkesan menyepelekan tugas yang diberikan, dan salah satu jalan pintas yang dipilih oleh sebagian mahasiswa yang malas yaitu dengan menyewa jasa joki online.

Menurut artikel dari jurnal berjudul "Penilaian dan Evaluasi Pendidikan Tingkat Tinggi yang dikeluarkan pada 30 September 2019" Jasa joki online dikalangan mahasiswa sudah berkembang menjadi bisnis global (Fauzan, 2019). Maka dari itu untuk berdasarkan evaluasi harus melakukan hal-hal berikut salah satunya fokus pada kemungkinan terjadinya joki saat tes (Haryanto, 2020).

Untuk mengatasi permasalahan tersebut diatas peneliti memanfaatkan teknologi Biometrics
Authentication and Recognition. Dimana biometric itu sendiri sebagai teknologi untuk mengidentifikasi ciri biologis seseorang yang mana setiap individu memiliki karakteristik yang unik, dimana keunikan tersebut yang digunkaan untuk mengidentifikasi dan memverifikasi suatu dokumen, aplikasi, sistem, computer dan lain sebagainya (Sari, 2018) ini bekerja dengan cara menyimpan informasi biologis kedalam suatu database yang terpusat lalu dengan cryptography di kode sehingga proses identifikasi bisa dicapai dengan proses scan, dll. Biometric sendiri digolongkan menjadi dua tipe utama yaitu physiological characteristics yang lebih mengarah ke fisik seperti sidik jari, retina, face recognition, DNA, dan sebagainya sedangkan behavioural characteristiss mengarah pada cara bersikap individu yang unik (Sari, 2018).

Face Recognition adalah teknologi yang digunakan untuk mengidentifikasi dan memverifikasi identitas citra seseorang. Face recognition ini adalah salah satu aplikasi paling popular untuk analisis dan identifikasi citra. Sistem ini termasuk kategori biometric untuk system keamanan dan privasi (Kurniawan et al., 2017). Face recognition dirancang untuk mendeteksi dan mengenali orang saat citra mereka diambil dengan lensa kamera (Yeung et al., 2020).

Wajah sebagai salah satu bagian tubuh manusia yang memiliki keunikan yang permanen menjadi 
salah satu alasan mengapa wajah ini dimanfaatkan untuk mengenali identitas agar dapat dikenali oleh orang lain. Dalam penelitian ini permasalahan yang diangkat yaitu bagaimana melakukan pengenalan wajah mahasiswa dalam sistem absensi di elearning yang digunakan untuk mendeteksi wajah mahasiswa untuk dapat mengakses sistem elearning tersebut. Sistem absensi ini digunakan untuk dapat mengakses soal-soal yang berada didalam sistem elearning. Absensi dilakukan dengan menginputkan wajah untuk selanjutnya dilakukan pencocokan dengan citra yang terlebih dahulu dimasukan dalam database. Hal ini dilakukan untuk meminimalisir dan mengetahui apakah benar yang mengerjakan dan mengakses elearning tersebut yaitu mahasiswa itu sendiri bukan joki online.

Berdasarkan penelitian sebelumnya yang dilakukan oleh Dwi Nugraheny (Nugraheny, 2017) pengenalan citra dengan metode Euclidean menghasilkan rata-rata persentase keakuratan nilai kemiripan dengan Euclidean sebesar 93\%.

Pengenalan citra wajah sebagai Identifier menggunakan Metode PCA untuk melibatkan pengmbambilan komponen utama dari database untuk mengetahui keakuratan sistem dilakukan uji coba dengan input sebanyak 60 citra sehingga menghasilkan hasil performansi sistem $80 \%$ (Budi et al., 2018).

Pada penelitian dengan metode eigenface/PCA untuk mengidentifikasi wajah manusia memperoleh jarak Euclidean pada saat pengujian wajah menghasilkan nilai maksimum dan minimum berkisar antara $6.0000 \mathrm{e}+04$, sedangkan saat pengujian menggunakan citra selain wajah mendapatkan jarak Euclidean nilai maksimum dan minimum mencapai 8.034e+04 (Anam, 2018).

Beberapa penelitian terkait pengenalan wajah diantaranya telah dilakukan oleh Wiryadinata, dkk (Wiryadinata et al., 2017) menunjukkan hasil penelitian pengenalan wajah melalui webcam yang direpresentasikan dengan metode PCA berbasis eigenface menunjukkan tingkat keberhasilan dengan nilai sensitivitas sebesar 73,33\%, kekhususan 52,17\% dan akurasi $86,67 \%$.

Dalam penelitian lain yang dilakukan oleh Mulyono dkk (Mulyono et al., 2019) PCA juga telah terbukti mampu mengenali citra dengan baik dalam berbagai variasi ekspresi. Bahkan dapat mengenali citra wajah dengan berbagai macam tantangan seperti mendeteksi wajah setelah operasi plastic dan menggabungkannya dengan teknik rekonstruksi citra wajah. Selain itu PCA Eigenface dalam mengenali wajah juga memiliki tantangan berupa kekurangan iluminasi citra wajah, variasi ekspresi yang signifikan dan penggunaan aksesoris sehingga dalam penelitian ini menghasilkan akurasi cukup bervariasi dari $100 \%$ hingga $67 \%$ disetiap database.

Sedangkan dalam penelitian dengan melakukan identifikasi wajah manusia untuk sistem monitoring kehadiran perkuliahan menggunakan PCA menghasilkan identifikasi wajah pada proses pengujian dengan tingkat keberhasilan sebesar 90\% (Suhery \& Ruslianto, 2017).

Pada penelitian yang dilakukan penulis saat ini dilakukan dengan menggunakan metode Principal Component Analysis menggunakan pengukuran jarak Euclidean untuk mencari kemiripan ciri suatu citra serta menghasilkan nilai maksimum dan minimum, sehingga akan diperoleh output wajah yang dikenali dan tidak dikenali. Hasil eksperiment akan menunjukkan False Positive Rate dari angka terkecil yang menunjukkan jarak terdekat atau yang paling mirip dengan citra yang di-input atau citra yang diuji sebelumnya untuk dicocokan dengan citra di database maka menghasilkan min distance terkecil sebesar $0.832 \%$ dari citra wajah Baijingting dan min distance terbesar dari citra wajah Aidai dengan jarak sebesar $0.973 \%$.

\section{METODE PENELITIAN}

Desain sistem absensi otomatis dengan memanfaatkan pengenalan wajah yang akan di usulkan untuk dikembangkan dengan tujuan untuk membantu proses absensi perkuliahan dalam suatu perguruan tinggi yang dilakukan dengan bantuan wajah masing-masing mahasiswa dengan tujuan untuk menghindari adanya Joki elearning. Dalam prosesnya citra diambil dari wajah mahasiswa yang sedang melaksanakan kuliah secara daring, dalam hal ini penulis mengambil sampel dataset dari kaggle yang merupakan citra wajah manusia baik laki-laki maupun perempuan dengan berbagai pose dan ekspresi wajah yang berbeda-beda.

Dalam pengimplementasiannya citra akan diolah dengan menghilangkan noise selanjutnya akan dilakukan deteksi wajah berdasarkan data wajah yang tersimpan dalam database untuk selanjutnya dilakukan pengecekan wajah sesuai nama masingmasing yang telah tersimpan dalam database.

\subsection{Dataset}

Dataset AFDB Face diambil dari kaggle https://www.kaggle.com/muhammeddalkran/masked -facerecognition terdiri dari total 90.000 citra wajah normal yang diambil dari 460 orang dengan berbagai pose serta 5000 citra dari 525 orang bermasker (Dalkiran, 2020). Dengan ukuran citra sebesar 146x127 pixel. Namun dalam penelitian ini peneliti hanya menggunakan citra wajah normal atau wajah tanpa masker.

Namun dalam penelitian ini peneliti hanya menggunakan citra sebanyak 50 dari 10 orang, sehingga masing-masing diambil 5 pose wajah untuk melakukan pengujian. 
Berikut sampel dataset yang diambil dari 10 orang tanpa masker dengan 5 pose wajah yang ditampilkan dalam Tabel 1:

Tabel 1. Sampel Citra AFDB Face

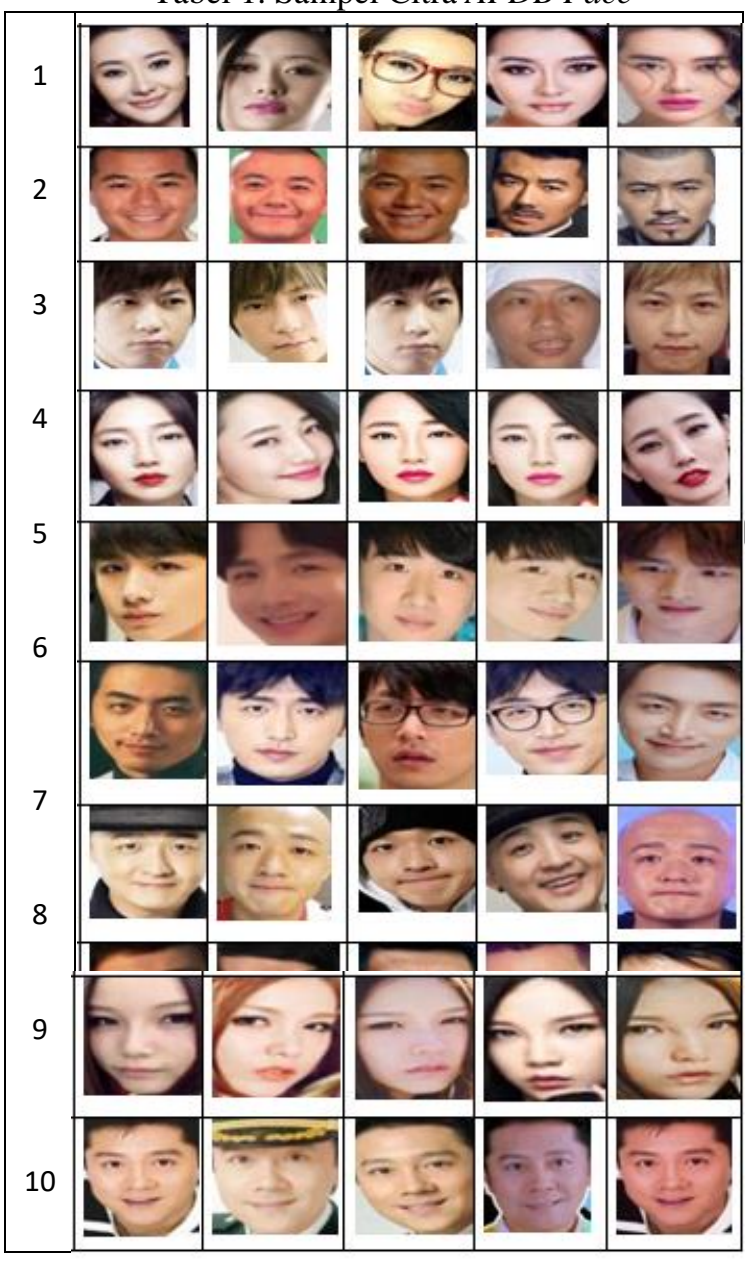

Nomor pada tabel merupakan keterangan foto dengan beberapa pose dari nama-nama berikut:

1. Aidai

2. Anhu

3. Axin

4. Baibaihe

5. Baijingting

6. Baike

7. Baobeier

8. Baojianfeng

9. Benxi

10. Baiguoqing

\subsection{Metodologi Sistem}

Berikut gambaran metodologi alur kerja absensi face recognition dengan metode PCA:

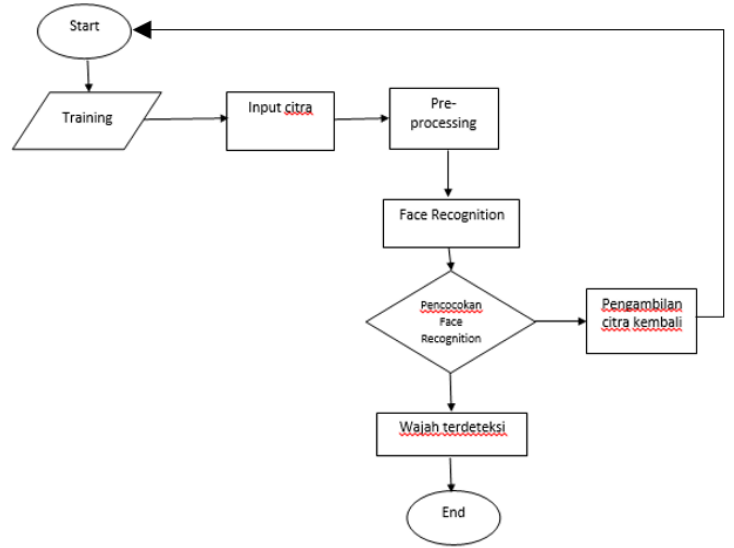

Gambar. 1 Metodologi Sistem

Dari gambar representasi model sistem tersebut berikut penjelasannya:

a. Training data

Pada tahap ini dilakukan training terhadap dataset yang digunakan, tahap ini dilakukan pembacaan directory untuk memastikan apakah seluruh citra didalam database sudah terbaca semua atau belum.

b. Proses pengambilan citra

Pada tahap ini sistem akan mengambil citra yang akan diproses yakni citra Face

c. Tahap pre-processing

Setelah citra diperoleh maka selanjutnya sistem akan menuju tahap pre-processing, dengan melakukan resize citra, mengubah menjadi citra blur, dan melakukan proses thresholding menjadi citra biner.

d. Tahap Face Recognition

Pada tahap face recognition dilakukan prediksi dengan metode Priciple Component Analysis (PCA) dengan

e. Tahap pencocokan face recognition dengan database sistem

Pada tahap ini akan diketahui apakah wajah yang diinput cocok dengan salah satu citra yang ada di dalam database

Dari hasil tahap face recognition dengan algoritma tersebut diatas, maka diperoleh prediksi wajah yang selanjutnya masuk tahap pencocokan wajah yang diinput dengan sample wajah yang sebelumnya telah disimpan dalam database, jika proses pencocokan wajah ditemukan maka prediksi yang dihasilkan tinggi dengan begitu proses absensi berhasil, jika tidak wajah yang diinput tidak ditemukan maka akan kembali keproses awal yaitu proses pengambilan citra Pada tahap face recognition dilakukan dengan menggunakan metode PCA. Selanjutnya akan diketahui kemiripan ciri dari suatu citra yang diinput dengan kumpulan citra yang terdapat dalam database. Dalam proses prediksi ini juga menghasilkan nilai maksimum dan minimum, sehingga akan diperoleh output wajah yang dikenali dan tidak dikenali yang akan menunjukkan False Positive Rate. 


\section{HASIL DAN PEMBAHASAN}

Dari hasil threshold mengubah citra menjadi citra biner, maka menghasilkan citra sebagai berikut:

Tabel 2. Hasil Ekstraksi Citra Biner

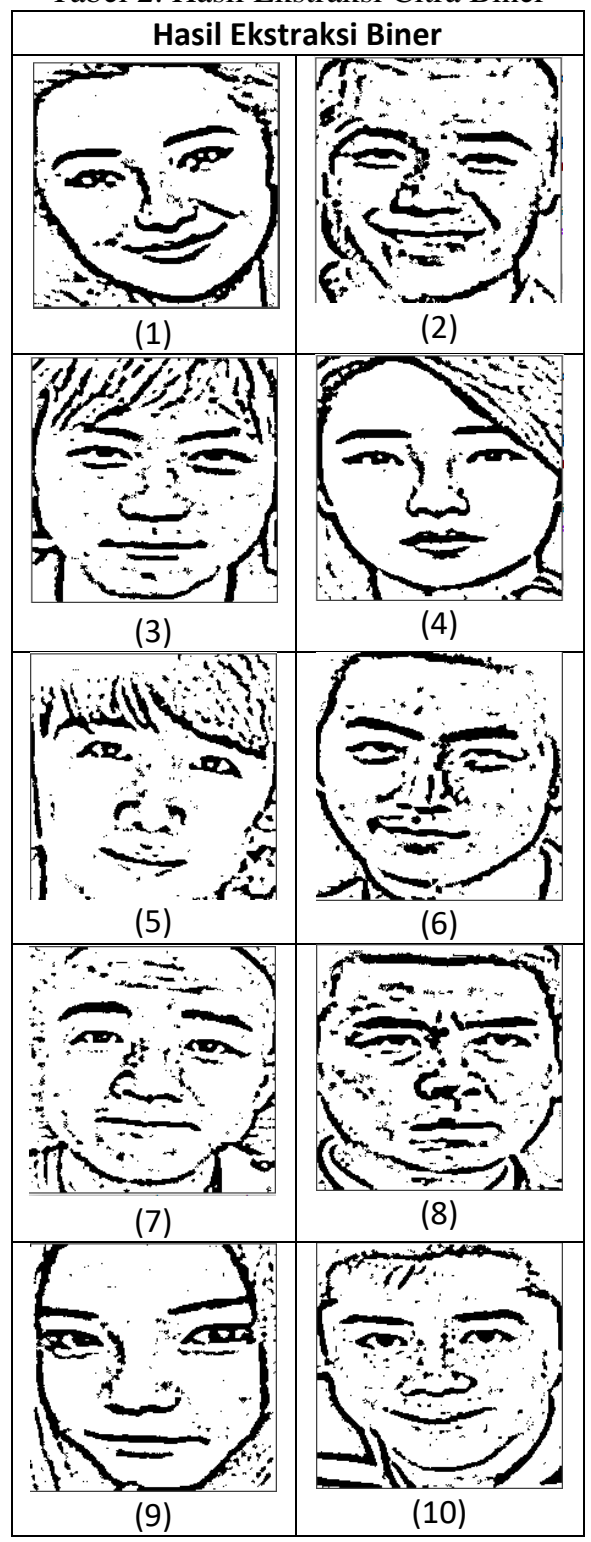

Nilai jarak euclidean terkecil dari masing-masing citra dapat dilihat pada tabel berikut:

Tabel 3. Jarak Euclidean

\begin{tabular}{|c|c|c|}
\hline No & $\begin{array}{c}\text { Citra } \\
\text { Wajah }\end{array}$ & Min Distance \\
\hline 1 & Aidai & $0.973 \%$ \\
\hline 2 & Anhu & $0.942 \%$ \\
\hline 3 & Axin & $0.955 \%$ \\
\hline 4 & Baibaihe & $0.853 \%$ \\
\hline 5 & Baijingting & $0.832 \%$ \\
\hline 6 & Baike & $0.934 \%$ \\
\hline 7 & Baobeier & $0.889 \%$ \\
\hline
\end{tabular}

\begin{tabular}{|c|c|c|}
\hline 8 & Baojianfeng & $0.956 \%$ \\
\hline 9 & Benxi & $0.937 \%$ \\
\hline 10 & Caiguoqing & $0.857 \%$ \\
\hline
\end{tabular}

Dari tabel tersebut diambil dari hasil jarak terdekat atau min distance dari hasil perhitungan metode Euclidean pada PCA yang diuji dari maisng-masing citra. Maka dari hasil yang diperoleh memperoleh jarak terkecil sebesar $0.832 \%$ dari citra Baijingting dan jarak terbesar dari citra Aidai dengan jarak sebesar $0.973 \%$.

\section{KESIMPULAN}

Berdasarkan penelitian yang dilakukan pada pengenalan wajah dengan menggunakan metode Principle Component Analysis (PCA) dengan mencari nilai jarak kemiripan dengan metode Euclidean, menunjukkan False Positive Rate dari angka terkecil dari masing-masing citra yang menunjukkan jarak terdekat yakni min distance sebesar $0.832 \%$ dari citra wajah Baijingting dan jarak terbesar dari citra wajah Aidai dengan min distance sebesar $0.973 \%$. Sehingga berdasarkan hasil False Positive Rate dalam sistem pegenalan wajah tersebut citra wajah Baijingting merupakan citra wajah yang paling mudah dikenali dibandingkan dengan citra wajah lainnya.

\section{REFERENSI}

Anam, M. K. (2018). Metode Eigenface / Principle Component Analysis ( PCA ) Untuk Identifikasi Wajah Manusia. 6(2), 82-88.

Budi, A., Suma'inna, S., \& Maulana, H. (2018). Pengenalan Citra Wajah Sebagai Identifier Menggunakan Metode Principal Component Analysis (PCA). Jurnal Teknik Informatika, 9(2), $166-175$ https://doi.org/10.15408/jti.v9i2.5608

Dalkiran, M. (2020). Real World Fasked Face Recognition Dataset (RMFRD). https://www.kaggle.com/muhammeddalkran/ masked-

facerecognition?select=AFDB_masked_face_ dataset

Fauzan, A. (2019). Mahasiswa Indonesia di Universitas Australia Gunakan Layanan Joki Bikin Tugas Kuliah. https://kabarkampus.com/2019/10/mahasiswaindonesia-di-universitas-australia-gunakanlayanan-joki-bikin-tugas-kuliah/

Haryanto. (2020). Evaluasi pembelajaran; Konsep dan Manajemen. In UNY Press. 
Kurniawan, V., Wicaksana, A., \& Prasetiyowati, M. I. (2017). The implementation of eigenface algorithm for face recognition in attendance system. Proceedings of 2017 4th International Conference on New Media Studies, CONMEDIA 2017, 2018-Janua, 118-124. https://doi.org/10.1109/CONMEDIA.2017.826 6042

Nugraheny, D. (2017). Metode Nilai Jarak Guna Kesamaan Atau Kemiripan Ciri Suatu Citra (Kasus Deteksi Awan Cumulonimbus Menggunakan Principal Component Analysis). Angkasa: Jurnal Ilmiah Bidang Teknologi, $7(2)$, https://doi.org/10.28989/angkasa.v7i2.145

Sari, A. C. (2018). Biometrics Authentication and Recognition.

https://socs.binus.ac.id/2018/11/29/biometricsauthentication-and-recognition/

Suhery, C., \& Ruslianto, I. (2017). Identifikasi Wajah Manusia untuk Sistem Monitoring Kehadiran Perkuliahan menggunakan Ekstraksi Fitur Principal Component Analysis (PCA). Jurnal Edukasi Dan Penelitian Informatika (JEPIN), 3(1), 9. https://doi.org/10.26418/jp.v3i1.19792

Wahyu Mulyono, I. U., Ignatius Moses Setiadi, D. R., Susanto, A., Rachmawanto, E. H., Fahmi, A., \& Muljono. (2019). Performance Analysis of
Face Recognition using Eigenface Approach. Proceedings - 2019 International Seminar on Application for Technology of Information and Communication: Industry 4.0: Retrospect, Prospect, and Challenges, ISemantic 2019, 1216.

https://doi.org/10.1109/ISEMANTIC.2019.88 84225

Wiryadinata, R., Istiyah, U., Fahrizal, R., Priswanto, P., \& Wardoyo, S. (2017). Sistem Presensi Menggunakan Algoritme Eigenface dengan Deteksi Aksesoris dan Ekspresi Wajah. Jurnal Nasional Teknik Elektro Dan Teknologi Informasi (JNTETI), 6(2), 222-229. https://doi.org/10.22146/jnteti.v6i2.319

Yeung, D., Balebako, R., Gutierrez Gaviria, C., \& Chaykowsky, M. (2020). Face Recognition Technologies: Designing Systems that Protect Privacy and Prevent Bias. In Face Recognition Technologies: Designing Systems that Protect Privacy and Prevent Bias. https://doi.org/10.7249/rr4226 